\title{
Structure and the Shear Bond Strength of Two Pit and Fissure Sealants
}

\author{
VIORICA TARMURE ${ }^{1}$, RADU SEPTIMIU CAMPIAN ${ }^{1}$, ECATERINA IONESCU², DOINA PRODAN ${ }^{3}$, MARIANA PACURAR ${ }^{4 *}$, \\ ELINA TEODORESCU ${ }^{2}$, ANDREEA SIMONA POP1 \\ 1 Iuliu Hatieganu University of Medicine and Pharmacy, Faculty of Dental Medicine, 33 Motilor Str., 400001, Cluj Napoca, Romania \\ ${ }^{2}$ Carol Davila University of Medicine and Pharmacy, Faculty of Dental Medicine, 4-6 Eforie Str., 050037, Bucharest, Romania \\ ${ }^{3}$ Babes Bolyai University, Raluca Ripan Institute for Research in Chemistry, 30 Fantanele Str., 400294, Cluj-Napoca, Romania \\ ${ }^{4}$ Tirgu Mures University of Medicine and Pharmacy, Faculty of Dental Medicine, 38 Gheorghe Marinescu Str., 540139, Targu \\ Mures, Romania
}

\begin{abstract}
Resin-based pit and fissure sealant materials are heterogeneous materials with two principal components: the resin matrix and the filler particles. The shear bond strength test holds great importance for providing insight into the adhesion of these materials and, also, it is a screening mechanism for predicting clinical performance. The purposes of the present study are to investigate the structure of surface and the shear bond strength for two commercial pit and fissure sealants, Fissurit (VOCO) and Pit \&Fissure (DMP) sealer. Seal Fissurit had the highest shear strength, and the difference was statistically significant between two tested materials.
\end{abstract}

Keywords: Resin-based pit and fissure sealant, structure of surface, shear bond strenght

Sealantmaterials were developed in the 1960s and have been used widely since then.

Resin composites are used for a variety of applications in dentistryincluding butnot limited to restorative materials, cavity liners, pit and fissure sealants, cores and buildups, inlays, onlays, crowns, provisional restorations, cements for single or multiple tooth prostheses and orthodontic devices, endodontic sealers, and root canal posts [1].

In figure 1 are presented the two resin-based pit and fissure sealant materials used in the study.

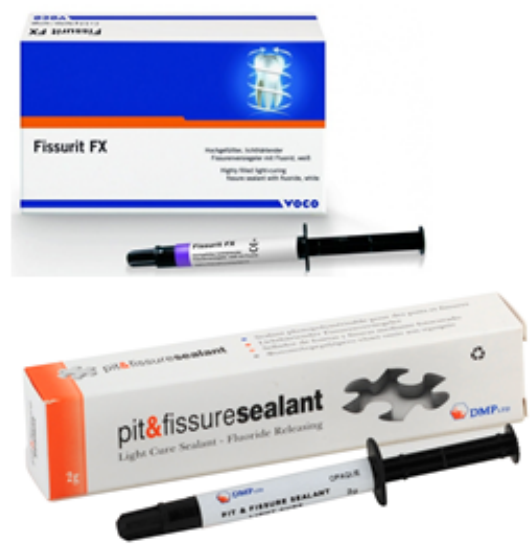

Fig. 1. The two resinbased pit and fissure sealant materials used in the study

The resin based fissure sealants (FS) are bonded to the underlying enamel by the use of the acid etch technique. Their caries preventive property is based on the establishment of a tight seal, which prevents leakage of nutrients to the microflora in the deeper parts of the fissure [2]. Dental sealants can be applied to the occlusal surfaces of teeth to penetrate anatomic surface pits and fissures and form a physical barrier on the tooth surface [3].

The strengths on material in the fracture show amount of power that is necessary to generate a breaking. This necessary energy for breaking represents in fact the hardness of the material. The restoration materials must have the capacity to oppose some applications forces which result of the fabrication and the masticator process.

The settlement of the mechanical properties is achieved throughout the magnitude of force, the application nature, flexural, strength, rigidity and rate wear.
When a force is applied on a material and tends to deform it, the material develops a resistance against the applied force.

Generally, a force will be applied axially (flexural or compression) or may be a tensile, shearing or twisting force.

The purposes of the present study are to investigate the structure of surface and the shear bond strength for two commercial pit and fissure sealants (Fissurit (VOCO) and Pit \&Fissure (DMP) sealer).

\section{Experimental part}

Materials and methods

The present in vitro study was conducted on 20 carries free surfaces of premolars, extracted for orthodontic purposes. On either side of the proximal surface, the teeth selected were cleaned with hand scalers to remove necrotic tissue, blood debris, stains and calculus. They were then washed with a toothbrush under running tap water. The mesial or distal surfaces were cleaned. The samples were then stored in artificial saliva [4].

Teeth were randomly divided into two groups: group 1 and group 2, each having 10 samples of teeth. In group 1, the FissuritFX (Voco) sealant was used and in group 2, the Pit \& Fissure Sealant (DMP) sealant was used. The surface of the enamel was planned and finished using a 600 grain abrasive paper. After being grouped and cleaned, the enamel surfaces of each tooth were etched for $30 \mathrm{~s}$ with $37 \%$ phosphoric acid and then washed with water, $15 \mathrm{~s}$. After drying each specimen for $30 \mathrm{~s}$, the sealant was applied on the enamel surfaces ( $3 \mathrm{~mm}$ in diameter and $4 \mathrm{~mm}$ in length), and was light cured for three s intervals, one from the top and two from the sides. Recordings were made after $10 \mathrm{~min}$ from sealing the enamel and after a month from sealing the enamel.

The obtained data were statistically processed with the Anova test. The mean values of the two sealing materials were compared. The $p$ threshold of significance was 0.05 . The materials used in this study are presented in table 1.

In order to determine the morphology of the obtained powders and in order to investigate the surfaces of the samples subjected to the solubility test, before and after

*email: marianapac@yahoo.com; Phone: (+40)744952183 


\begin{tabular}{|c|c|c|c|c|}
\hline $\begin{array}{l}\text { Trade } \\
\text { name }\end{array}$ & Materials & $\begin{array}{c}\text { The organic } \\
\text { matrix }\end{array}$ & Inorganic fillers & Manufacturer \\
\hline $\begin{array}{l}\text { Fissurit } \\
\text { FX }\end{array}$ & $\begin{array}{l}\text { resin-based } \\
\text { dental } \\
\text { material for }\end{array}$ & $\begin{array}{l}\text { Bis-GMA- } \\
\text { UDMA } \\
(91 \%)\end{array}$ & $\begin{array}{l}\text { (Borosilicateglass } \\
\text { (particle size: } 99 \% \mathrm{~L} \\
>1 \mu \mathrm{m} \text { ). } \mathrm{NaF} 3 \% \\
\text { coresponds to } 1.3 \% \\
\text { fluoride content) }\end{array}$ & $\begin{array}{l}\text { VOCO GmbH } \\
\text { Cuxhaven } \\
\text { Germany }\end{array}$ \\
\hline $\begin{array}{l}\text { DMP } \\
\text { Pit \& } \\
\text { Fissure } \\
\text { Sealant }\end{array}$ & $\begin{array}{l}\text { the sealing } \\
\text { of pits and } \\
\text { fissures }\end{array}$ & $\begin{array}{l}\text { Mixture of } \\
\text { methacrylate } \\
\text { ester } \\
\text { monomers. }\end{array}$ & $\begin{array}{l}\text {-Opaque and } \\
\text { radiopaque fillers } \\
\text {-Fluorine compounds }\end{array}$ & $\begin{array}{l}\text { DMP Hellenic } \\
\text { Dental Store } \\
\text { Markopoulos } \\
\text { Industrial } \\
\text { Zone, Greece }\end{array}$ \\
\hline
\end{tabular}

Table 1

THE COMPOSITION FOR FISSURIT FX $[5,6]$ AND DMP PIT \& FISSURE SEALANT testing, an INSPECT S (FEI Co) microscope was used. As the electronic microscope is a magnifying device that can be used for the morphological examination of tissues, of contours and geometrical forms of microparticles, its applicability and relevance to the present study are unquestionable.

For obtaining the samples, in order to determine the shear forces, a steel circle has been filled with PMMA, and the root of the premolars has been inserted to the point of the enamel-cement junction. The mobile part, made out of teflon, had a square hole in the middle, with a $3 \mathrm{~mm}$ side and a $4 \mathrm{~mm}$ depth. This part is intimately adapted to the prepared surface of the tooth, the hole being centered on the prepared surface. Then, the hole is filled with the sealing material. In this matrix, the sealing material in applied in $2 \mathrm{~mm}$ layers, successively light cured. After polymerase, the sample is detached from the matrix and is kept in the artificial saliva until the testing moment. The shear forces were registered with the help of a universal testing apparatus LOYD - Soft Nexygen for mechanical testing), using a speed of $0.5 \mathrm{~mm} / \mathrm{min}$.

The retention force $\mathrm{S}[\mathrm{MPa}]$ of the tested sealing material was calculated by dividing the cadence force $F(N)$ to the surface $A\left(\mathrm{~mm}^{2}\right)$ of the sealing segment: $S=F / A$.

\section{Results and discussions}

Scanning electron microscopy (SEM): In figure 2, images of the structure surface of the dental enamel sealed with the Fissurit material, magnified x 1000(a), x1500(b) and also the structure of the Fissurit sealant surface magnified $x 10000$ (c), can be visualised. The sealing material presents a surface with inorganic particles ( under $2 \mu \mathrm{m}$ ) and also agglomerations of these particles, of smaller dimentions. Also, opalescent particles are present. A uniform distribution of the inorganic filling in the organic matrix can also be observed.

In figure 3, the structure images of the dental enamel sealed with the Pit and Fissure sealant magnified x 1000(a) and also the structure of the Pit and Fissure sealant surface magnified $x 10000(b)$, can be visualised.

It can be remarqued that the Pitt and Fissure sealant presents hybride fillings, with some inorganic particles of 50-60 $\mu \mathrm{m}$ surrounded by much smaller particles.

The acid etching process of the enamel surfaces of the teeth has an important role in the adhesion of the sealant, as itcreates microscopic retentions (microscopic fissures) in which the sealant to penetrate.

If the utilized sealing material has a uniform composition and a fine inorganic composition, it will manage to penetrate much easier the microscopic fissures created 0 the surface of the enamel, throughout the acid etching process, thus enhancing a adequate adhesion [6].

Resin-based pit and fissure sealant materials, such as FissuritFX are heterogeneous materials with two principal components: the resin matrix and the filler particles [7].

The shear bond strength test holds great importance for providing insight into the adhesion of these materials. Also it is a screening mechanism for predicting clinical performance $[8,9]$.

The sheer bond strength depends on the many factors such as: composition of the resin matrix, viscosity of the resin-based materials, the size of the filler particles, and type of filler material [10].
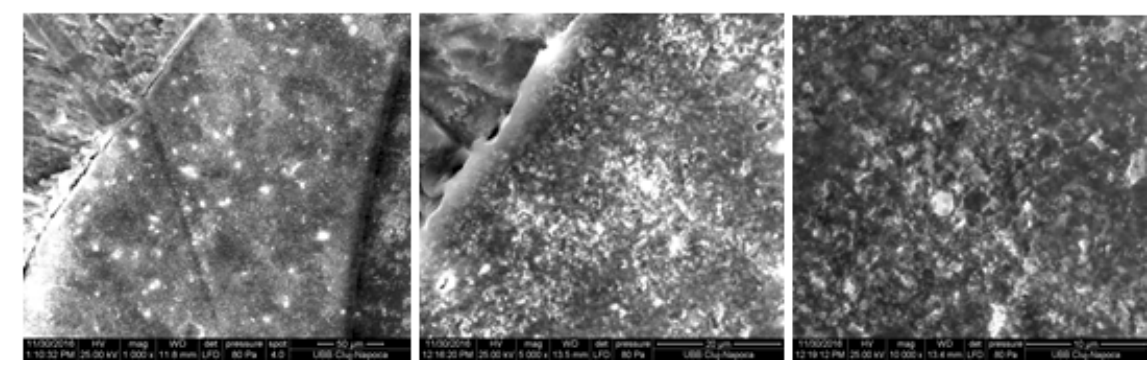

Fig. 2. SEM immage of a tooth surface sealed with the Fissurit sealant at $x 1000$ magnification

(a) and at $x 5000$ magnification (b); Fissurit sealant at $x 10000$ magnification (c)
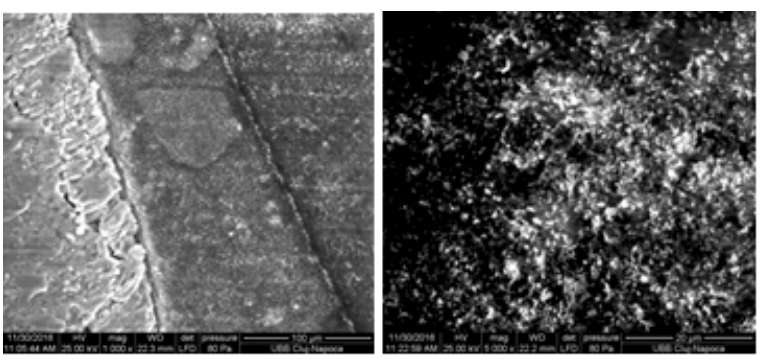

Fig 3. SEM immage of a tooth surface sealed with the Pit and Fissure sealant - DMP at $x 1000$ magnification (a); Pit and Fisure sealant - DMP at $x 5000$ magnification (b) 


\begin{tabular}{|c|c|c|c|c|c|c|c|c|}
\hline \multirow[b]{2}{*}{ Sample } & \multirow{2}{*}{$\begin{array}{c}\text { Mean } \\
\text { value } \\
{[\mathrm{MPa}]}\end{array}$} & \multirow{2}{*}{ SD } & \multirow[b]{2}{*}{$\mathbf{N}$} & \multirow[b]{2}{*}{ SEM } & \multicolumn{2}{|c|}{$P$ (t test) } & \multicolumn{2}{|c|}{ ANOVA } \\
\hline & & & & & $\begin{array}{c}\text { vs. } \\
\text { Fissurit }\end{array}$ & \begin{tabular}{|c} 
vs. \\
Pit \& \\
Fissure
\end{tabular} & $\mathrm{p}$ & $\mathrm{F}$ \\
\hline Fissurit & 15.33 & 0.757 & 10 & 0.329 & 0.001 & 0.003 & & \\
\hline $\begin{array}{l}\text { Pit \& } \\
\text { Fissure }\end{array}$ & 12.76 & 0.580 & 10 & 0.390 & 0.000 & 1.000 & 0.000 & 92.3 \\
\hline
\end{tabular}

Table 2

STATISTIC ANALYSIS OF THE ADHESION TO ENAMEL ACCORDING TO THE SEALING MATERIA

[SD -standard deviation, $\mathrm{N}$ - number of measurements,

SEM - standard error of the mean values, $\mathrm{p}<0.05$ (statistically signifiant)].

The mean values obtained following the adhesion to the enamel test are presented in table 2, under the form of the ratio between measured force and the corresponding areas, with the statistical comparison of the two sealing materials

Analysing the standard variation we have found that there are significant statistic differences for the Fissurit sealing material compared to the Pitt and Fissure sealing material $(p<0.003)$, from the measured adhesion point of view. The registered values of the adhesion at the level of sealant-enamel interface for the Fissurit and Pit and Fissure sealants were significantly different. The resistance to adhesion was higher at the Fissurit sealant-enamel adhesion, the mean value being $15.33 \mathrm{MPa}$.

The shear resistance of the adhesion was generally utilised in order to evaluate the adhesive systems in vitro. Studies to determine the performances of different systems and techniques are important, especially for the relative values obtained, butnumerical comparisons are notalways possible. By consulting other similar studies, we find that there is a great variability of the shear tests results, according to the utilised method. So, the different values of the MPa are cot compared between authors, but rather it is preferred to explore the trends in studied material behaviour.

Meerbeek and al [11], show that the fundamental principle of adhesion to tooth substrate is based upon an exchange process by which inorganic tooth material is exchanged for synthetic resin. They affirm that this process involves two phases: removing calcium phosphates by which microporosities are exposed at the enamel and the infiltration and subsequent in situ polymerization of resin within the created surface microporosities. There is an additional chemical interaction between functional monomers and tooth substrate components [11]. The mechanical stresses tend to concentrate on the angles and protuberances of the particles [12]. The Pit \& Fissure sealer exhibit filler particles, those are considerably larger than the FissuritFX. The main difference between the tested sealants relies on the presence of fillers amounts and shapes of fillers, since both materials are resin-based and contain fluoride in their composition. Sealing ability and shear bond strength differs among different fissure sealants used [13]. Probably higher value for shear strength increases the longevity of sealant.

After Jumanca et al [14], health professionals should always take into account that fissure sealants and other dental materials, currently used, have limitations, and one major limitation is related to microleakage.
In the researches of Saveanu et al [15], is underlined that most of the differences statistically significant were obtained by analyzing color criterion, generally the diacrylic hybrid composite resin with ceramic particles showing the best scores.

\section{Conclusions}

Seal Fissurit had the highest shear strength, and the difference was statistically significant between two tested materials.

Most filler particles of both the pit and fissure sealants are of irregular shape. An optimal resin composite should mimic structural, physical and mechanical characteristics of dentin and enamel.

\section{References}

1.FERRACANE J. L., Dent Materials, 27, no. 1, 2011, p. 29.

2.WELBURY R., RAADAL M., LYGIDAKIS N.A., Eur J Paediatr Dent., 5, no.3, 2004, p.179.

3.ANUSAVICE K.J., SHEN C., RAWLS R.R, Phillips' science of dental materials, 12, Elsevier Health Sciences, Science of Dental Materials, Missouri, US: Elsevier/Saunders; 2013.

4.BOGERT T.R., GARCIA-GODOY F., Pediatr. Dent., 14, no.1, 1992, p. 50.

5.POGGIO C., ANDENNA G., CECI M., BELTRAMI R., COLOMBO M., CUCCA L., J Clin Exp Dent, 8, no. 3, 2016, p. 284.

6.POP, A.S., CAMPIAN R.S., PACURAR, M., TEODORESCU, E., BUNTA, O., TARMURE, V., Mat. Plast., 54, no.1, 2017, p.129.

7.DUKIC W., LULIC DUKIC O., MILARDOVIC S., VINDAKIJEVIC Z, Collegium antropologicum, 31, no. 4, 2007, p. 1019.

8.VISURI S.R., GILBERT J .L., WRIGHT D.D., WIGDOR H.A., WALSH J.T. JR., J. Dent. Res., 75, no. 1, 1996, p. 599.

9.DE SOUZA-GABRIEL A.E., DO AMARAL F.L., PÉCORA J.D., PALMADIBB R.G., CORONA S.A., Oper Dent., 31, no. 2, 2006, p. 212.

10.SENER Y., BOTSALI M.S., KUCUKYILMAZ E., TOSUN G., SAVAS S.J ., Res. Dent., 2, no. 2, 2014, p. 88.

11.VAN MEERBEEK B., MUNCK J.DE., YOSHIDA Y., INOUE S., VARGAS M.,VIJ AY P., LANDUYT K. VAN., LAMBRECHTS P., VANHERLE G., Operative Dentistry, 28, no.3, 2003, p. 215.

12.BEUN S., BAILLY C., DEVAUX J., LELOUP G., Dent Materials, 28, no. 4, 2012, p. 349.

13.PARDI V., SINHORETI M.A.C., PEREIRA A.C., AMBROSANO G.M.B., MARCELO DE CASTRO MENEGHIM M.C., Braz. Dent. J., 17, no.1, 2006. 14.J UMANCA, D., GALUSCAN, A., POPESCU, L.A., GHIORGHE, A., ANDRIAN, S., SINESCU, C., Rev.Chim.(Bucharest), 67, no.11, 2016 15.SAVEANU, C.I., DANILA, I., DANILA, V., DRAGOS, O., CHEPTEA, C., Rev.Chim.(Bucharest), 67, no.11, 2016, p. 2337

Manuscript received: 15.12 .2016 